\title{
PENERAPAN MODEL COOPERATIVE LEARNING TIPE STUDENT TEAM ACHIEVMENT DIVISION (STAD) UNTUK MENINGKATKAN HASIL BELAJAR IPS MATERI KEANEKARAGAMAN SUKU BANGSA PADA SISWA KELAS VI SD NEGERI 3 LUENG PUTU
}

\author{
Siti Rosnidah \\ SD Negeri 3 Lueng Putu \\ e-mail : sitirosnidahnidah@gmail.com
}

\begin{abstract}
Tujuan penelitian ini untuk mendeskripsikan kualitas pembelajaran IPS melalui tipe STADm pada siswa kelas VI SD Negeri 3 Lueng Putu. Penelitian tindakan kelas ini dilaksanakan dalam dua siklus. Setiap siklus terdiri dari perencanaan, pelaksanaan, observasi, refleksi. Subjek penelitian adalah guru, siswa kelas VI SD Negeri 3 Lueng Putu. Teknik pengumpulan data menggunakan tes dan nontes. Analisis data menggunakan analisis deskriptif kuantitatif dan kualitatif. Hasil penelitian menunjukkan: (1) Keterampilan guru siklus I memperoleh skor 19 kategori baik, dan siklus 2 skor 30 kategori sangat baik. (2) Aktivitas siswa siklus I memperoleh skor 17,14 kategori cukup, dan siklus 2 skor 25,32 kategori baik. (3) Persentase ketuntasan klasikal hasil belajar siswa siklus 1 sebesar 55\%, dan meningkat pada siklus 2 menjadi 91\%. Kesimpulan penelitian melalui tipe STAD dapat meningkatkan kualitas pembelajaran IPS meliputi keterampilan guru, aktivitas siswa, hasil belajar siswa kelas SD Negeri 3 Lueng Putu. Disarankan agar guru menerapkan pembelajaran kooperatif tipe STAD agar siswa dapat belajar aktif dan mandiri
\end{abstract}

Kata Kunci: Cooperative Learning Tipe Student Team Achievment Division (Stad), Hasil Belajar

\begin{abstract}
ABSTRAK
The purpose of this study was to describe the quality of social studies learning through the type of STADm in class VI students of SD Negeri 3 Lueng Putu. This classroom action research was carried out in two cycles. Each cycle consists of planning, implementation, observation, reflection. The research subjects were teachers, class VI students at SD Negeri 3 Lueng Putu. The technique of collecting data uses tests and non-tests. Data analysis used quantitative and qualitative descriptive analysis. The results of the study showed: (1) The skill of the first cycle teacher got a score of 19 good categories, and the second cycle of the score 30 was very good. (2) Activity of the first cycle students get a score of 17.14 enough categories, and the second cycle scores 25.32 in the good category. (3) The percentage of classical completeness in student learning outcomes in cycle 1 is $55 \%$, and increases in cycle 2 to $91 \%$. The conclusion of the study through the type of STAD can improve the quality of social studies learning including teacher skills, student activities, learning outcomes of SD Negeri 3 Lueng Putu. It is recommended that teachers apply STAD type cooperative learning so students can learn actively and independently
\end{abstract}

Keywords: Cooperative Learning Student Team Achievement Division (Stad) Type, Learning Outcomes.

\section{LATAR BELAKANG}

Dalam Undang-Undang Republik Indonesia No. 20 Tahun 2003 tentang Sistem Pendidikan Nasional Bab II Pasal 3 dinyatakan bahwa pendidikan nasional berfungsi mengembangkan kemampuan dan membentuk watak serta peradaban bangsa yang bermartabat dalam rangka mencerdaskan bangsa, bertujuan untuk mengembangkan potensi siswa agar menjadi 
manusia yang beriman dan bertakwa kepada Tuhan Yang Maha Esa, berakhlak mulia, sehat, berilmu, cakap, kreatif, dan menjadi warga negara yang demokratis serta bertanggung jawab.

Guru dalam menerapkan pembelajaran lebih menekankan pada metode yang mengaktifkan guru, pembelajaran yang dilakukan guru kurang kreatif, lebih banyak menggunakan metode ceramah dan kurang mengoptimalkan media pembelajaran. Sehingga siswa kurang aktif dalam pembelajaran tersebut. Siswa hanya diam saja dan mudah jenuh dalam pembelajaran. Selain itu kurangnya motivasi yang diberikan guru, juga menjadi faktor kurangnya hasil belajar siswa dalam mengikuti pembelajaran IPS.

Pembelajaran IPS pada siswa kelas VI SD Negeri 3 Lueng Putu. Berdasarkan refleksi awal peneliti menunjukkan bahwa pembelajaran IPS masih belum optimal, selain karena materi pembelajaran IPS cukup banyak, dalam pembelajaran guru kurang menggunakan strategi pembelajaran yang menarik minat siswa, sehingga siswa kurang aktif dan cepat merasa bosan. Berdasarkan hasil peneliti antusiasme siswa ketika pelajaran IPS sangat rendah. Pada saat pelajaran IPS, anak-anak merasa malas dan tidak bersemangat.

Hal itu didukung data dari pencapaian hasil ulangan harian pelajaran IPS siswa kelas VI semester II tahun pelajaran 2016/2017 masih dibawah Kriteria Ketuntasan Minimal (KKM) yang ditetapkan sekolah yaitu 65. Dari 22 siswa data hasil belajar ulangan harian. Siswa yang mengalami ketuntasan belajar sebanyak 8 anak (36\%) sedangkan siswa yang tidak tuntas dalam belajar sebanyak 14 siswa (64\%). Nilai rata- rata yang diperoleh adalah 60,23 .

Berdasarkan latar belakang yang telah peneliti uraikan diatas maka peneliti tertarik untuk menelitu sejauh mana efektivitas pendekatan cooperative learning tipe STAD ini dalam meningkatkan hasil belajar siswa pada pelajaran IPS. Adapun yang menjadi judul dalam penelitian tindakan kelas ini adalah "Penerapan Model Cooperative Learning Tipe Student Team Achievment Division Meningkatkan Hasil Belajar IPS Materi Keanekaragaman Suku Bangsa pada Siswa Kelas VI SD Negeri 3 Lueng Putu”

\section{KERANGKA TEORITIS \\ Pengertian Pembelajaran Kooperatif Tipe STAD}

Pembelajaran kooperatif tipe Student Team Achievement Division (STAD) yang dikembangkan oleh Robert Slavin dan teman-temannya di Universitas John Hopkin (dalam Slavin,1995:14) merupakan pembel ajaran kooperatif yang paling sederhana, dan merupakan pembelajaran kooperatif yang cocok digunakan oleh guru yang baru mulai menggunakan pembelajaran kooperatif.

Student Team Achievement Divisions (STAD) adalah salah satu tipe pembelajaran kooperatif yang paling sederhana. Siswa ditempatkan dalam tim belajar beranggotakan empat orang yang merupakan campuran menurut tingkat kinerjanya, jenis kelamin dan suku. Guru menyajikan pelajaran kemudian siswa bekerja dalam tim untuk memastikan bahwa seluruh anggota tim telah menguasai pelajaran tersebut. Akhirnya seluruh siswa dikenai kuis tentang materi itu dengan catatan, saat kuis mereka tidak boleh saling membantu.

Model Pembelajaran Koperatif tipe STAD merupakan pendekatan Cooperative Learning yang menekankan pada aktivitas dan interaksi diantara siswa untuk saling memotivasi dan saling membantu dalam menguasai materi pelajaran guna mencapai prestasi yang maksimal. Guru yang menggunakan STAD mengajukan informasi akademik baru kepada siswa setiap minggu mengunakan presentasi Verbal atau teks.

Menurut Slavin (dalam Noornia, 1997: 21) ada lima komponen utama dalam pembelajaran kooperatif metode STAD, yaitu:

\section{a. Penyajian Kelas}

Penyajian kelas merupakan penyajian materi yang dilakukan guru secara klasikal 
dengan menggunakan presentasi verbal atau teks. Penyajian difokuskan pada konsepkonsep dari materi yang dibahas. Setelah penyajian materi, siswa bekerja pada kelompok untuk menuntaskan materi pelajaran melalui tutorial, kuis atau diskusi.

b. Menetapkan siswa dalam kelompok

Kelompok menjadi hal yang sangat penting dalam STAD karena didalam kelompok harus tercipta suatu kerja kooperatif antar siswa untuk mencapai kemampuan akademik yang diharapkan. Fungsi dibentuknya kelompok adalah untuk saling meyakinkan bahwa setiap anggota kelompok dapat bekerja sama dalam belajar. Lebih khusus lagi untuk mempersiapkan semua anggota kelompok dalam menghadapi tes individu. Kelompok yang dibentuk sebaiknya terdiri dari satu siswa dari kelompok atas, satu siswa dari kelompok bawah dan dua siswa dari kelompok sedang. Guru perlu mempertimbangkan agar jangan sampai terjadi pertentangan antar anggota dalam satu kelompok, walaupun ini tidak berarti siswa dapat menentukan sendiri teman sekelompoknya.

c. Tes dan Kuis

Siswa diberi tes individual setelah melaksanakan satu atau dua kali penyajian kelas dan bekerja serta berlatih dalam kelompok. Siswa harus menyadari bahwa usaha dan keberhasilan mereka nantinya akan memberikan sumbangan yang sangat berharga bagi kesuksesan kelompok.

d. Skor peningkatan individual

Skor peningkatan individual berguna untuk memotivasi agar bekerja keras memperoleh hasil yang lebih baik dibandingkan dengan hasil sebelumnya. Skor peningkatan individual dihitung berdasarkan skor dasar dan skor tes. Skor dasar dapat diambil dari skor tes yang paling akhir dimiliki siswa, nilai pretes yang dilakukan oleh guru sebelumnya melaksanakan pembelajaran kooperatif metode STAD.

e. Pengakuan kelompok

Pengakuan kelompok dilakukan dengan memberikan penghargaan atas usaha yang telah dilakukan kelompok selama belajar. Kelompok dapat diberi sertifikat atau bentuk penghargaan lainnya jika dapat mencapai kriteria yang telah ditetapkan bersama. Pemberian penghargaan ini tergantung dari kreativitas guru.

\section{Pengertian Hasil Belajar}

Hasil belajar merupakan tujuan akhir dilaksanakannya kegiatan pembelajaran di sekolah. Hasil belajar dapat ditingkatkan melalui usaha sadar yang dilakukan secara sistematis mengarah kepada perubahan yang positif yang kemudian disebut dengan proses belajar. Akhir dari proses belajar adalah perolehan suatu hasil belajar siswa. Hasil belajar siswa di kelas terkumpul dalam himpunan hasil belajar kelas. Semua hasil belajar tersebut merupakan hasil dari suatu interaksi tindak belajar dan tindak mengajar. Dari sisi guru, tindak mengajar di akhiri dengan proses evaluasi hasil belajar, sedangkan dari sisi siswa, hasil merupakan berakhirnya penggal dan puncak proses belajar (Dimyati dan Mudjiono, 2009: 3).

Menurut Sudjana (2010: 22), hasil belajar adalah kemampuan yang dimiliki siswa setelah menerima pengalaman belajar. Selanjutnya Warsito (dalam Depdiknas, 2006: 125) mengemukakan bahwa hasil dari kegiatan belajar ditandai dengan adanya perubahan perilaku ke arah positif yang relatif permanen pada diri orang yang belajar. Sehubungan dengan pendapat itu, maka Wahidmurni, dkk. (2010: 18) menjelaskan bahwa sesorang dapat dikatakan telah berhasil dalam belajar jika ia mampu menunjukkan adanya perubahan dalam dirinya. Perubahan-perubahan tersebut di antaranya dari segi kemampuan berpikirnya, keterampilannya, atau sikapnya terhadap suatu objek.

Jika dikaji lebih mendalam, maka hasil belajar dapat tertuang dalam taksonomi Bloom, yakni dikelompokkan dalam tiga ranah (domain) yaitu domain kognitif atau kemampuan berpikir, domain afektif atau sikap, dan domain psikomotor atau keterampilan. Sehubungan dengan itu, Gagne (dalam Sudjana, 2010: 22) mengembangkan 
kemampuan hasil belajar menjadi lima macam antara lain: (1) hasil belajar intelektual merupakan hasil belajar terpenting dari sistem lingsikolastik; (2) strategi kognitif yaitu mengatur cara belajar dan berfikir seseorang dalam arti seluas-luasnya termaksuk kemampuan memecahkan masalah; (3) sikap dan nilai, berhubungan dengan arah intensitas emosional dimiliki seseorang sebagaimana disimpulkan dari kecenderungan bertingkah laku terhadap orang dan kejadian; (4) informasi verbal, pengetahuan dalam arti informasi dan fakta; dan (5) keterampilan motorik yaitu kecakapan yang berfungsi untuk lingkungan hidup serta memprestasikan konsep dan lambang.

Untuk mengetahui hasil belajar seseorang dapat dilakukan dengan melakukan tes dan pengukuran. Tes dan pengukuran memerlukan alat sebagai pengumpul data yang disebut dengan instrumen penilaian hasil belajar. Menurut Wahidmurni, dkk. (2010: 28), instrumen dibagi menjadi dua bagian besar, yakni tes dan non tes. Selanjutnya, menurut Hamalik (2006: 155), memberikan gambaran bahwa hasil belajar yang diperoleh dapat diukur melalui kemajuan yang diperoleh siswa setelah belajar dengan sungguh-sungguh. Hasil belajar tampak terjadinya perubahan tingkah laku pada diri siswa yang dapat diamati dan diukur melalui perubahan sikap dan keterampilan. Perubahan tersebut dapat diartikan terjadinya peningkatan dan pengembangan yang lebih baik dibandingkan dengan sebelumnya.

\section{Pengertian Keanekaragaman Suku Bangsa.}

Bangsa Indonesia terdiri dari bermacam-macam suku bangsa. Tentunya banyak sekali perbedaan yang ada. Ada yang berbeda warna kulit, bentuk fisik, dan budayanya. Perbedaan jangan dipermasalahkan. Justru dengan adanya perbedaan tersebut, kita jadikan suatu kekayaan sehingga tercipta suasana yang aman, tenteram, dan harmonis. Sikap menghormati adalah sikap menghargai dan mengakui keberadaan harkat dan martabat manusia meski berbeda-beda suku bangsa. "Bhinneka Tunggal Ika" yang terdapat pada pita Burung Garuda Pancasila lambang Negara Indonesia mengandung arti "Berbeda-beda, tetapi tetap satu jua." Ada juga semboyan yang menyatakan "Bersatu kita teguh, bercerai kita runtuh." Makna dari semboyan tersebut adalah supaya kita bersatu padu menghalau semua ancaman yang dapat memecah belah persatuan dan kesatuan bangsa kita. Dalam sejarah, bangsa kita telah berhasil mengusir penjajah dari bumi Nusantara karena adanya persatuan dan kesatuan para pemuda dari seluruh Nusantara.

Sejak zaman dahulu bangsa Indonesia dikenal sebagai masyarakat yang majemuk. Hal ini tercermin dari semboyan "Bhinneka tunggal Ika" yang artinya berbeda-beda tetapi tetap satu. Kemajemukan yang ada terdiri atas keragaman suku bangsa, budaya, agama,ras,danbahasa. Adat istiadat, kese nian, kekerabatan, bahasa, dan bentuk fisik yang dimiliki oleh suku-suku bangsa yang ada di Indonesia memang berbeda, namun selain perbedaan suku-suku itu juga memiliki persamaan antara lain hukum, hak milik tanah, persekutuan, dan kehidupan sosialnya yang berasaskan kekeluargaan.

Suku bangsa adalah golongan manusia yang terikat oleh kesadaran dan identitas akan kesatuan kebudayaan. Orang-orang yang tergolong dalam satu suku bangsa tertentu, pastilah mempunyai kesadaran dan identitas diri terhadap kebudayaan suku bangsanya, misalnya dalam penggunaan bahasa daerah serta mencintai kesenian dan adati stiadat.

Suku-suku bangsa yang tersebar di Indonesia merupakan warisan sejarah bangsa, persebaran suku bangsa dipengaruhi oleh faktor geografis, perdagangan laut, dan kedatangan para penjajah di Indonesia. perbedaan suku bangsa satu dengan suku bangsa yang lain di suatu daerah dapat terlihat dari ciri-ciri berikut ini. dari pengertian diatas dapat penulis simpulkan 
keaneka ragaman suku bangsa adalah kesatuan masyarakat Indonesia yang memiliki identitas yang hidup dengan ikatan budaya sebagai warisan sejarah bangsa.

a. Tipe fisik, seperti warna kulit, rambut, dan lain-lain.

b. Bahasa yang dipergunakan, misalnya Bahasa Batak, Bahasa Jawa, Bahasa Madura, dan lain-lain.

c. Adat istiadat, misalnya pakaian adat, upacara perkawinan, dan upacara kematian.

d. Kesenian daerah, misalnya Tari Janger, Tari Serimpi, Tari Cakalele, dan Tari Saudati.

e. Kekerabatan, misalnya patrilineal (sistem keturunan menurut garis ayah) dan matrilineal (sistem keturunan menurut garis ibu).

f. fBatasan fisik lingkungan, misalnya Badui dalam dan Badui luar.

(https://ictkelompokblog.wordpress.com/ma teri/keragaman-suku-bangsa-dan-budaya-diindonesia/)

\section{METODOLOGI PENELITIAN Waktu dan Tempat Penelitian}

Penelitian ini dilakukan selama 3 bulan pada semester II tahun pelajaran 2016/2017. Pelaksanaan penelitian dilakukan pada harihari efektif sesuai dengan jadwal pelajaran. Penelitian dilaksanakan di SD Negeri 3 Lueng

\section{Pendekatan penelitian}

Pada proses penelitian hendaknya dapat menentukan suatu metode penelitian yang akan digunakan,hal ini berdasarkan pada suatu pemahaman bahwa metode penelitian dapat dijadikan suatu cara atau langkah untuk memperoleh suatu data, meganalisis data, sehingga pada akhirnya akan mendapatkan hasil dari sasaran serta tujuan penelitian yang dilakukan. Dalam mencapai tujuan yang diinginkan pada penelitian yang dilakukan maka penting sekali bagi peneliti untuk memilih metode penelitian yang tepat sebagai metode penelitian yang akan dicapai.
Penggunaan metode penelitian sangat tergantung kepada permasalahan yang akan dibahas, hal ini dapat diartikan bahwa penggunaan suatu metode penelitian dapat dilihat dari segi efektifitas, efesiensi serta relevansinya metode penelitian tersebut dengan permasalahan pada sebuah penelitian yang dilakukan. Metode penelitian dikatakan efektif apabila selama pelaksanaan penelitian dapat terlihat adanya suatu perubahan positif kearah tujuan yang diharapkan, sedangkan apabila dalam pelaksanaan penelitian penggunaan waktu,fasilitas,biaya,dan tenaga dapat terlaksana dengan sehemat mungkin akan tetapi tujuan penelitian tetap tercapai maka metode tersebut dikatakan efisien dalam sebuah penelitian. Selanjutnya penelitian dapat dikatakan relevan apabila penelitian tersebut berjalan dengan lancer serta dapat menghasilkan hasil sesuai dengan tujuan penelitian serta adanya kesesuaian antara waktu penggunaan hasil pengolahan dengan tujuan yang akan dicapai pada suatu penelitian tidak terjadi penyimpangan.

Pendekatan dalam penelitian ini menggunakan pendekatan penelitian kualitatif karena penelitian ini bersifat deskriptif dan naturalistik. Penelitian ini bersifat deskriptif karena hanya mendeskripsikan tentang hasil peningkatan pembelajaran IPS Materi Keragaman Suku Bangsa Melalui Penerapan Model Cooperative Learning Tipe Student Team Achievment Division (STAD) Pada siswa kelas VI SD Negeri 3 Lueng Putu. Pendekatan kualitatif bersifat naturalistik karena penelitian ini memang terjadi secara alamiah, apa adanya, dalam situasi normal yang tidak memanipulasi keadaan dan kondisinya. Kedua sifat penelitian kualitatif tersebut menuntut keterlibatan peneliti secara langsung (partisipasi aktif) baik pada awal pembelajaran maupun yang terjadi setelah diterapkannya tindakan di lapangan.

\section{Jenis Penelitian}

Jenis penelitian ini adalah jenis Penelitian Tindakan Kelas (Class Action Research) karena penelitian dilakukan oleh 
Gurudi sekolah nya sendiri dengan jalan merancang, melaksanakan, dan merefleksikan tindakan secara kolaboratif dan partisipatif dengan tujuan untuk memperbaiki kinerja Guru sehingga hasil belajar siswa dapat meningkat. Penelitian Tindakan Kelas yang digunakan dalam penelitian ini adalah Model Kurt Lewin yang terdiri dari empat komponen, yaitu: a) Perencanaan (Planning); b) Tindakan (Acting; c) Pengamatan (Observing; dan d) Refleksi (Refecting)

\section{Rancangan Penelitian}

Rancangan model penelitian yang dipakai dalam penelitian ini adalah menggunakan Penelitian Tindakan Kelas model spiral atau siklus menurut Arikunto (2009:16), bertujuan apabila dalam pelaksanaan tindakan ditemukan adanya kekurangan, maka dapat dilakukan perbaikan yang dilanjutkan pada siklus berikutnya sampai target diinginkan tercapai. Dalam setiap siklus terdiri dari empat tahapan yaitu perencanaan, pelaksanaan tindakan, observasi, dan refleksi Rancangan Penelitian sebagai berikut

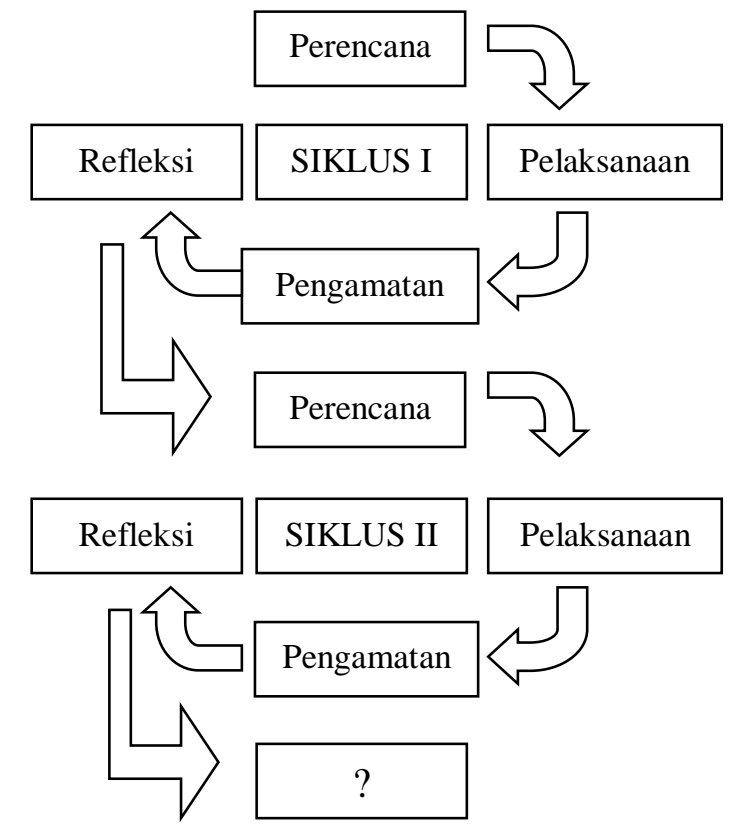

Menurut Arikunto, (2009:17) langkahlangkah penelitian dilaksanakan dalam tahapan

\section{Perencanaan}

Didalam tahap perencanaan, peneliti menentukan fokus peristiwa yang perlu mendapatkan perhatian khusus untuk diamati, kemudian dilanjutkan membuat sebuah instrumen pengamatan untuk membantu peneliti mengambil data dalam merekam fakta yang terjadi selama tindakan

\section{Pelaksanaan Tindakan}

Pelaksanaan tindakan yakni implementasi atau penerapan isi rancangan di dalam kancah, yaitu mengenakan tindakan di kelas. Dalam tahap pelaksanaan tindakan guru melaksanakan pembelajaran dengan menggunakan Penerapan Model Cooperative Learning Tipe Student Team Achievment Division (STAD) sesuai materi akan diajarkan. Kolaborator berperan untuk melakukan pengamatan dalam pelaksanaan tindakan atau kegiatan pembelajaran

\section{Observasi}

Observasi atau pengamatan yaitu pelaksanaan pengamatan oleh pengamat yang dilakukan secara teliti dan dan melakukan pencatatan secara sistematis Pelaksanaan observasi atau pengamatan bersamaan dengan pelaksanaan tindakan atau kegiatan pembelajaran. Dalam tahap ini kolaborator melakukan pengamatan dan mendokumentasikan keterampilan guru, aktivitas siswa, hasil belajar. Pengamatan dilakukan dengan menggunakan pedoman observasi.

\section{Refleksi}

Refleksi adalah perenungan kembali atas apa yang telah dilakukan untuk dijadikan cermin (pedoman) perbaikan bagi aktivitas selanjutnya (Poerwanti, 2009:5.45). Dalam tahap ini peneliti dan kolaborator mendiskusikan hasil pengamatan selama pelaksanaan tindakan berlangsung. Kekurangan yang ditemui dalam siklus sebelumnya digunakan sebagai dasar penyusunan rencana pelaksaan tindakan pada siklus selanjutnya. Dengan demikian maka siklus selanjutnya akan berjalan lebih baik dari pada siklus sebelumnya. 


\section{Subyek Penelitian}

Subyek penelitian dalam penelitian ini adalah guru Kelas VI dan siswa berjumlah 22 siswa dengan jumlah siswa laki-laki 8 dan jumlah siswa perempuan 14 tahun ajaran 2016/2017

\section{Instrumen Penelitian}

Instrumen yang digunakan dalam penelitian ini terdiri dari

1. Observasi

2. Catatan Harian (Field Note)

3. Test

4. Dokumentasi

\section{Teknik Pengumpulan Data}

Teknik pengumpulan data yang dilakukan dalam penelitian ini meliputi teknik tes dan teknik non tes, sebagai berikut: 1. Tes

Teknik tes adalah seperangkat tugas yang harus dikerjakan atau sejumlah pertanyaan yang harus dijawab oleh peserta didik untuk mengukur tingkat pemahaman dan penguasaannya terhadap cakupan materi yang dipersyaratkan dan sesuai dengan tujuan pengajaran tertentu (Poerwanti, 2008:1.5).

Dalam penelitian ini teknik tes berupa tes tertulis yaitu dengan menggunakan alat pengumpulan data berupa soal evaluasi yang diberikan kepada siswa pada setiap akhir pertemuan dalam setiap siklus. Tes dalam penelitian ini digunakan untuk mengukur atau memberi angka terhadap proses pembelajaran ataupun pekerjaan siswa sebagai hasil belajar yang merupakan cerminan tingkat penguasaan terhadap materi yang diajarkan.

2. Nontes

Teknik nontes adalah suatu alat penilaian yang digunakan untuk mendapatkan informasi tertentu tentang keadaan peserta tes tanpa menggunakan tes (Hamdani, 2011:316). Dalam penelitian ini, teknik nontes dilakukan dengan observasi, dokumentasi, catatan lapangan. a. Observasi.

Teknik pengumpulan data lewat megnamati setiap kejadian berlangsung serta mencatatnya dengan alat observasi sesuai hal-hal diamati atau diteliti (Sanjaya, 2010:86). Observasi dalam penelitian ini digunakan untuk mengamati aktivitas siswa dan keterampilan guru dalam pembelajaran IPS dengan menggunakan pendekatan Model Cooperative Learning Tipe Student Team Achievment Division (STAD) selama pelaksanaan tindakan dalam penelitian berlangsung.

b. Teknik Dokumentasi

Dokumentasi berasal dari kata dokumen, yang artinya barang-barang tertulis. Dalam melaksanakan metode dokumentasi, peneliti menyelidiki bendabenda tertulis seperti buku-buku, majalah, dokumenen, peraturan-peraturan, notulen rapat, catatan harian, dan sebagainya (Novianti, 2012). Dalam penelitian ini metode dokumen digunakan untuk memperoleh data nama-nama siswa subyek penelitian dan nilai atau hasil evaluasi siswa yang digunakan untuk mengetahui besarnya peningkatan hasil belajar siswa.

\section{HASIL PENELITIAN DAN PEMBAHASAN}

Hasil penelitian tindakan kelas melalui model pembelajaran kooperatif tipe Student Teams Achivement Division (STAD) yang diperoleh dari hasil tes dan nontes yang terlaksana dalam dua siklus dengan setiap siklusnya satu kali pertemuan selama tiga jam pelajaran. Hasil tes tersebut diperoleh dari observasi pada saat pembelajaran dan evaluasi yang dilaksanakan di setiap akhir pertemuan pada setiap siklus untuk melihat dan mengukur peningkatan pemahaman materi koperasi oleh siswa. Data kualitatif yang diperoleh yaitu berupa hasil observasi pada saat berlangsungnya pembelajaran yang berupa keterampilan guru dan aktivitas siswa yang disajikan dalam bentuk data kualitatif dan deskripsi. Hasil tes yang diperoleh di setiap evaluasi berupa data kuantitatif. Berikut ini akan di-paparkan hasil penelitian 
yang terdiri atas keterampilan guru, aktivitas siswa dalam proses pembelajaran IPS, dan hasil belajar IPS melalui model pembelajaran kooperatif tipe STAD pada siswa kelas VI SD Negeri 3 Lueng Putu

\section{Pra Siklus}

Hasil Belajar siswa sebelum dilaksanakan pendekatan Model Cooperative Learning Tipe Student Team Achievment Division (STAD) dapat Peneliti gambarkan seperti pada table berikut ini

Tabel 1 Perolehan Data Hasil Belajar Pra Siklus

\begin{tabular}{|l|c|c|}
\hline \multirow{2}{*}{ Prestasi Belajar } & \multicolumn{2}{|c|}{$\begin{array}{c}\text { Hasil Tes Pra Siklus } \\
\text { (Skor Dasar) }\end{array}$} \\
\cline { 2 - 3 } & $\begin{array}{c}\text { Banyak } \\
\text { Siswa }\end{array}$ & $\begin{array}{c}\text { Persentase } \\
(\%)\end{array}$ \\
\hline $\begin{array}{l}\text { Jumlah siswa } \\
\text { tuntas belajar } \\
\text { (skor } \geq 65)\end{array}$ & 8 & $36 \%$ \\
\hline $\begin{array}{l}\text { Jumlah siswa } \\
\text { tidak tuntas } \\
\text { belajar (skor } \leq \\
\text { 65) }\end{array}$ & \multicolumn{2}{|c|}{$\mathbf{6 0 , 2 3}$} \\
\hline \begin{tabular}{l} 
Rata-rata kelas \\
\hline
\end{tabular}
\end{tabular}

\section{Siklus I}

\section{a. Observasi}

Berikut ini hasil Observasi yang dilakukan oleh teman sejawat terhadap Ketrampilan Guru dalam menggunakan pendekatan Model Cooperative Learning Tipe Student Team Achievment Division (STAD) pada pembelajaran IPS materi keragaman suku Bangsa.

Tabel 2 Hasil Observasi Keterampilan Guru Siklus I

\begin{tabular}{|c|l|c|}
\hline No & \multicolumn{1}{|c|}{$\begin{array}{c}\text { Indikator } \\
\text { Keterampilan Guru } \\
\text { Menggunakan } \\
\text { Kooperatif Tipe STAD }\end{array}$} & Perolehan Skor \\
\hline 1 & $\begin{array}{l}\text { Keterampilan membuka } \\
\text { pelajaran }\end{array}$ & 2 \\
\hline 2 & Penguasaan bahan ajar & 3 \\
\hline 3 & Keterampilan bertanya & 2 \\
\hline
\end{tabular}

\begin{tabular}{|c|l|c|}
\hline 4 & $\begin{array}{l}\text { Keterampilan } \\
\text { membimbing diskusi } \\
\text { kelompok }\end{array}$ & 3 \\
\hline 5 & $\begin{array}{l}\text { Keterampilan memberi } \\
\text { penghargaan }\end{array}$ & 2 \\
\hline 6 & $\begin{array}{l}\text { Keterampilan } \\
\text { membimbing presentasi }\end{array}$ & 2 \\
\hline 7 & $\begin{array}{l}\text { Keterampilan mengelola } \\
\text { kelas }\end{array}$ & 3 \\
\hline 8 & $\begin{array}{l}\text { Keterampilan menutup } \\
\text { pelajaran }\end{array}$ & $\mathbf{1 9}$ \\
\hline Jumlah skor yang diperoleh & $\mathbf{2 , 3 7}$ \\
\hline Rata-rata skor & Cukup \\
\hline Kategori &
\end{tabular}

Observasi aktivitas siswa dengan mengamati seluruh siswa di dalam kelas yang mengikuti pembelajaran yaitu ada 22 siswa dengan jumlah siswa laki- laki sebanyak 4 dan jumlah siswa perempuan sebanyak 18 pada pelaksanaan tindakan siklus I pada pembelajaran IPS melalui model pembelajaran kooperatif tipe STAD di kelas VI SD Lueng Putu. Aktivitas siswa dalam setiap indikator diamati dengan menggunakan lembar observasi aktivitas siswa yang telah dibuat didapatkan data sebagai berikut:

Tabel 3 Hasil Observasi Aktivitas Siswa Siklus I

\begin{tabular}{|c|l|c|c|}
\hline No & $\begin{array}{c}\text { Indikator } \\
\text { Aktivitas } \\
\text { Siswa }\end{array}$ & $\begin{array}{c}\text { Jumlah } \\
\text { total } \\
\text { skor }\end{array}$ & $\begin{array}{c}\text { Rata- } \\
\text { rata } \\
\text { Skor }\end{array}$ \\
\hline 1 & $\begin{array}{l}\text { Kesiapan } \\
\text { belajar siswa }\end{array}$ & 55 & 2,50 \\
\hline 2 & $\begin{array}{l}\text { Keterlibatan } \\
\text { siswa dalam } \\
\text { pembelajaran }\end{array}$ & 46 & 2,09 \\
\hline 3 & $\begin{array}{l}\text { Kemampuan } \\
\text { menjawab } \\
\text { pertanyaan } \\
\text { guru }\end{array}$ & 47 & 2,14 \\
\hline 4 & $\begin{array}{l}\text { Kemampuan } \\
\text { menyampaik } \\
\text { an pendapat }\end{array}$ & 47 & 2,14 \\
\hline 5 & $\begin{array}{l}\text { Kemampuan } \\
\text { bertanya pada } \\
\text { guru }\end{array}$ & 44 & 2,00 \\
\hline
\end{tabular}




\begin{tabular}{|c|l|c|c|}
\hline 6 & $\begin{array}{l}\text { Kemampuan } \\
\text { mempresenta } \\
\text { sikan hasil } \\
\text { dis-kusi } \\
\text { kelompok }\end{array}$ & 45 & 2,05 \\
\hline 7 & $\begin{array}{l}\text { Kemampuan } \\
\text { merangkum/ } \\
\text { menyimpulka } \\
\text { n materi }\end{array}$ & 46 & 2,09 \\
\hline 8 & $\begin{array}{l}\text { Kemampuan } \\
\text { mengerjakan } \\
\text { soal evaluasi }\end{array}$ & 47 & 2,14 \\
\hline $\begin{array}{l}\text { Jumlah Skor yang } \\
\text { diperoleh }\end{array}$ & \multicolumn{2}{|c|}{$\mathbf{3 7 7}$} \\
\hline $\begin{array}{l}\text { Rata-rata skor } \\
\text { total }\end{array}$ & \multicolumn{2}{|c|}{ Cukup } \\
\hline Kategori & \multicolumn{2}{|l|}{} \\
\hline \multicolumn{2}{|l|}{} \\
\hline
\end{tabular}

b. Refleksi

Setelah guru melakukan kegiatan belajar mengajar, observer dan guru sebagai peneliti mulai mengadakan refleksi tindakan ini dilakukan untuk mengetahui sejauh mana kekurangan dan kelebihan peneliti dalam pembelajaran. Untuk itu dalam kegiatan terjadi tanya jawab antara peneliti yaitu guru dengan observer menyangkut hal-hal yang diamati observer.

\section{c. Deskripsi Hasil Belajar Siswa}

Berdasarkan evaluasi pembelajaran IPS melalui model pembelajaran kooperatif tipe STAD pada siswa kelas VI SD Lueng Putu pada siklus I dibandingkan dengan data awal yang ada diperoleh data sebagai berikut

Tabel 4 Hasil Belajar Siklus I

\begin{tabular}{|c|c|c|}
\hline \multirow{2}{*}{ Prestasi Belajar } & \multicolumn{2}{|c|}{$\begin{array}{c}\text { Hasil Tes Siklus I } \\
\text { (Skor Dasar) }\end{array}$} \\
\cline { 2 - 3 } & $\begin{array}{c}\text { Banyak } \\
\text { Siswa }\end{array}$ & $\begin{array}{c}\text { Persentas } \\
\text { e (\%) }\end{array}$ \\
\hline & 12 & $55 \%$ \\
\hline $\begin{array}{l}\text { Jumlah siswa tidak } \\
\text { tuntas belajar (skor } \\
\leq 65)\end{array}$ & 10 & $45 \%$ \\
\hline Rata-rata kelas & \multicolumn{2}{|c|}{$\mathbf{6 6 , 3 6}$} \\
\hline
\end{tabular}

Tabel 5 Perbandingan Hasil Belajar Data Awal dengan Siklus I

\begin{tabular}{|c|l|l|l|}
\hline No & Pencapaian & $\begin{array}{c}\text { Data } \\
\text { awal }\end{array}$ & \multicolumn{1}{|c|}{$\begin{array}{c}\text { Data } \\
\text { Siklus I I }\end{array}$} \\
\hline 1 & Rata-rata & 60,23 & 66,36 \\
\hline 2 & $\begin{array}{l}\text { Persentase } \\
\text { Siswa } \\
\text { Tuntas }\end{array}$ & $36 \%$ & $36 \%$ \\
\hline 3 & $\begin{array}{l}\text { Persentase } \\
\text { Siswa Tidak } \\
\text { Tuntas }\end{array}$ & $64 \%$ & $64 \%$ \\
\hline
\end{tabular}

Siklus II

a. Observasi

Guru sebagai peneliti dan observer melakukan pengamatan tindakan. Pengamatan tindakan ini dilakukan untuk mengamati, merekam semua kejadian yang terjadi selama pemberian tindakan kepada siswa, baik yang muncul akibat diberikannya tindakan maupun efak dari tindakan itu sendiri, yang nantinya akan dijadikan sebagai bahan kolaborasi di tahap refleksi.

Adapun pengamatan dilakukan menggunakan lembar pengamatan yang telah disiapkan, guna untuk mengetahui sejauh mana pembelajaran cooperative learning tipe STAD dapat meningkatkan hasil siswa pada pelajaran tersebut.

Tabel 6 Hasil Observasi Keterampilan Guru Siklus II

\begin{tabular}{|c|l|c|}
\hline No & $\begin{array}{c}|c| \\
\text { Keterampilan Guru } \\
\text { Menggunakan } \\
\text { Kooperatif Tipe STAD }\end{array}$ & $\begin{array}{c}\text { Peroleha } \\
\text { n Skor }\end{array}$ \\
\hline 1 & $\begin{array}{l}\text { Keterampilan membuka } \\
\text { pelajaran }\end{array}$ & 4 \\
\hline 2 & Penguasaan bahan ajar & 4 \\
\hline 3 & Keterampilan bertanya & 4 \\
\hline 4 & $\begin{array}{l}\text { Keterampilan } \\
\text { membimbing diskusi } \\
\text { kelompok }\end{array}$ & 3 \\
\hline 5 & $\begin{array}{l}\text { Keterampilan memberi } \\
\text { penghargaan }\end{array}$ & 4 \\
\hline 6 & $\begin{array}{l}\text { Keterampilan } \\
\text { membimbing presentasi }\end{array}$ & 4 \\
\hline
\end{tabular}




\begin{tabular}{|c|l|c|}
\hline 7 & $\begin{array}{l}\text { Keterampilan mengelola } \\
\text { kelas }\end{array}$ & 3 \\
\hline 8 & $\begin{array}{l}\text { Keterampilan menutup } \\
\text { pelajaran }\end{array}$ & 4 \\
\hline Jumlah skor yang diperoleh & $\mathbf{3 0}$ \\
\hline Rata-rata skor & $\mathbf{3 , 7 5}$ \\
\hline Kategori & $\begin{array}{c}\text { Sangat } \\
\text { Baik }\end{array}$ \\
\hline
\end{tabular}

Hasil observasi aktivitas siswa pada pelaksanaan tindakan siklus II pada pembelajaran IPS melalui model pembelajaran kooperatif tipe STAD di kelas VI SDN 3 Lueng Putu didapatkan data sebagai berikut.

Tabel .7 Hasil Observasi Aktivitas Siswa Siklus II

\begin{tabular}{|c|l|c|c|}
\hline No & \multicolumn{1}{|c|}{$\begin{array}{c}\text { Indikator } \\
\text { Aktivitas Siswa }\end{array}$} & $\begin{array}{c}\text { Jumlah } \\
\text { total } \\
\text { skor }\end{array}$ & $\begin{array}{c}\text { Rata- } \\
\text { rata } \\
\text { Skor }\end{array}$ \\
\hline 1 & $\begin{array}{l}\text { Kesiapan belajar } \\
\text { siswa }\end{array}$ & 71 & 3,23 \\
\hline 2 & $\begin{array}{l}\text { Keterlibatan } \\
\text { siswa dalam } \\
\text { pembelajaran }\end{array}$ & 71 & 3,23 \\
\hline 3 & $\begin{array}{l}\text { Kemampuan } \\
\text { menjawab } \\
\text { pertanyaan guru }\end{array}$ & 67 & 3,05 \\
\hline 4 & $\begin{array}{l}\text { Kemampuan } \\
\text { menyampaikan } \\
\text { pendapat }\end{array}$ & 73 & 3,32 \\
\hline
\end{tabular}

\section{b. Hasil Belajar}

Berikut Hasil belajar pada siklus II dapat diketahui melalui tabel di bawah ini;

Tabel 8 Hasil Belajar Siklus II

\begin{tabular}{|l|c|c|}
\hline \multirow{2}{*}{ Prestasi Belajar } & \multicolumn{2}{|c|}{$\begin{array}{c}\text { Hasil Tes Siklus II } \\
\text { (Skor Dasar) }\end{array}$} \\
\cline { 2 - 3 } & $\begin{array}{c}\text { Banyak } \\
\text { Siswa }\end{array}$ & $\begin{array}{c}\text { Persentase } \\
(\%)\end{array}$ \\
\hline $\begin{array}{l}\text { Jumlah siswa } \\
\text { tuntas belajar } \\
\text { (skor } \geq 65)\end{array}$ & 20 & $91 \%$ \\
\hline $\begin{array}{l}\text { Jumlah siswa } \\
\text { tidak tuntas }\end{array}$ & 2 & $9 \%$ \\
\hline
\end{tabular}

\begin{tabular}{|l|l|}
\hline $\begin{array}{l}\text { belajar (skor } \leq \\
\text { 65) }\end{array}$ & \\
\hline Rata-rata kelas & $\mathbf{7 9 , 7 7}$ \\
\hline
\end{tabular}

Tabel .9 Perbandingan Hasil Belajar IPS Siswa Siklus I dan Siklus II

\begin{tabular}{|c|l|l|l|}
\hline No & Pencapaian & $\begin{array}{c}\text { Data } \\
\text { Siklus } \\
\text { I }\end{array}$ & $\begin{array}{c}\text { Data } \\
\text { Siklus II }\end{array}$ \\
\hline 1 & Rata-rata & 66,36 & 79,77 \\
\hline 2 & $\begin{array}{l}\text { Persentase } \\
\text { Siswa Tuntas }\end{array}$ & $55 \%$ & $91 \%$ \\
\hline 3 & $\begin{array}{l}\text { Persentase } \\
\text { Siswa Tidak } \\
\text { Tuntas }\end{array}$ & $45 \%$ & $9 \%$ \\
\hline
\end{tabular}

Berdasarkan hasil peneilitian ini membuktikan bahwa adanya peningkatan hasil belajar, aktivitas siswa dan guru pada pembelajaran IPS materi keanekaragaman suku bangsa dan budaya dengan menggunakan metode cooperative learning tipe STAD.

Dimana sebelum diberikan tindakan dengan menggunakan metode cooperative learning tipe STAD, terlihat aktivitas siswa sangat rendah dan kondisi seperti ini sangat mempengaruhi hasil belajar siswa pada setiap materi. Ini terbukti pada kondisi awal siswa hanya memperoleh nilai rata-rata 59,49 dan $8 \%$ siswa yang mencapai KKM yang ditentukan sekolah. Dimana SD Negeri 3 Lueng Putu menentukan KKM untuk kelas VI adalah 65. Hal ini disebabkan dalam pembelajaran IPS masih menggunakan metode ceramah dan tanya jawab, siswa hanya duduk, mendengarkan atau hanya menyelesaikan tugas, siswa merasa jeuh dan bosan.Ketika pelaksanaan tindakan siklus I ternyata adanya peningkatan hasil belajar dimana nilai rata-ratanya sudah mencapai 66,36 dengan ketuntasan belajar sebesar 55\% atau sebanyak 12 siswa yang sudah mencapai KKM, Hal ini disebabkan karena proses pembelajaran yang dilaksankan dengan 
menggunakan metode cooperative learning tipe STAD dapat membangkitkan motivasi belajar siswa sehingga berdampak pada hasil belajar. sekalipun sudah terjadi peningkatan hasil belajar namun belum memuaskan maka peneliti akan melanjutkan tindakan pada siklus II dengan merevisi segala kelemahan yang ada pada pelaksanaan siklus I.

Sesuai dengan hasil penelitian pada siklus II ternyata terjadi peningkatan, yang mana nilai rata-ratanya mencapai 79,77 dengan ketuntasan belajar mencapai $91 \%$, Jelas terlihat adanya peningkatan yang cukup signifikan. Hal ini dikarenakan para siswa sudah menunjukkan respon yang positif pada saat proses pembelajaran.

Berikut perolehan nilai rata-rata siswa, aktivitas siswa dan guru persiklus pada tindakan para siklus, siklus I dan siklus II pelajaran IPS materi keanekaragaman suku bangsa dengan menggunaka metode cooperative learning tipe STAD di kelas VI SD Negeri 3 Lueng Putu Kecamatan Bandar Baru:

Tabel 10 Hasil Analisis Nilai Penguasaan Konsep IPS Pra Siklus, Siklus I dan Siklus II

\begin{tabular}{|c|c|c|c|c|c|c|c|}
\hline \multirow{2}{*}{ No } & \multirow{2}{*}{$\begin{array}{c}\text { Ketun } \\
\text { tasan }\end{array}$} & \multicolumn{2}{|c|}{ Pra Siklus } & \multicolumn{2}{l|}{$\begin{array}{l}\text { Siklus } \\
\text { I }\end{array}$} & \multicolumn{2}{c|}{$\begin{array}{c}\text { Siklus } \\
\text { II }\end{array}$} \\
\cline { 3 - 8 } & & Jlh & $\%$ & Jlh & $\%$ & Jlh & $\%$ \\
\hline 1 & Tuntas & 8 & $36 \%$ & 12 & $55 \%$ & 20 & $91 \%$ \\
\hline 2 & $\begin{array}{l}\text { Belum } \\
\text { Tuntas }\end{array}$ & 14 & $64 \%$ & 10 & $45 \%$ & 2 & $9 \%$ \\
\hline \multicolumn{2}{|c|}{ Jumlah } & 22 & $100 \%$ & 22 & $100 \%$ & 22 & $100 \%$ \\
\hline
\end{tabular}

\section{KESIMPULAN}

Berdasarkan hasil penelitian yang telah diuraikan sebelumnya dari siklus I sampai siklus II diperoleh data adanya peningkatan hasil belajar dari satu siklus ke siklus dua, peningkatan hasil belajar pada siklus I dibandingkan sebelum diberlakukan tindakan dengan rata-rata nilai hasil belajar siswa sebelum ada tindakan adalah 60,23 dengan tingkat ketuntasan $36 \%$, sedangkan ketika diberikan tindakan pada siklus I diperoleh nilai rata-rata siswa adalah 66,36, dengan tingkat ketuntasan 55\%. Ini artinya sudah terjadi peningkatan tingkat ketuntasan belajar siswa dari pra siklus ke siklus I sebanyak $19 \%$.

Sementara pada siklus II dengan diperoleh peningkatan hasil belajar siswa yang cukup signifikan dengan penerapan metode cooperative learning tipe STAD, dimana rata-ratanya dari $55 \%$ di siklus I menjadi $91 \%$ pada siklus II.

Maka dapat disimpulkan bahwa penggunaan metode cooperative learning tipe STAD dapat meningkatkan hasil belajar IPS pada materi keanekaragam suku bangsa dikelas VI SD Negeri 3 Lueng Putu Kecamatan Bandar Baru. Hal ini terjadi karena metode cooperative learning tipe STAD pada IPS memberi kesempatan kepada siswa untuk dapat membangun pengetahuannya sendiri yang dimilikinya berdasarkan dunia nyata dan pengalaman langsung dalam penerapan kehidupan seharihari.

\section{DAFTAR PUSTAKA}

Arikunto Suharsimi ,2006, Penelitian Tindakan Kelas, Jakarta: Bumi Aksara

Dimyati dan Mujiono, 2002, Belajar dan Pembelajaran, Jakarta: Rineka

Gagne, 2010:2, Teaching Social Studies, Australia: Printice

Kemendikbud (2013), Peraturan Mentri Pendidikan dan Kebudayaan Indonesia Nomor 65 Tahun 2013 Tentang Standar Proses Pendidikan Dasar dan Menengah

Oemar Hamalik, 2003, Proses Belajar Mengajar,Jakarta Bumi Aksara

Slavin,1995:14 . Cooperative Learning : Analisis Model Pengembangan IPS. Jakarta : Bumi Aksara Cipta.

Sanjaya, 2010:86. Metoda Statistika. Bandung: Tarsito. 